Trikonomika

Volume 19, No. 1, June 2020, Page. 22-28

ISSN 1411-514X (print) / ISSN 2355-7737 (online)

\title{
SERVICE AND PATIENTS PARTICIPATION ON SATISFACTION AND TRUST
}

\author{
Bambang Suroto \\ bambangsuroto@unilak.ac.id \\ Hadiyati \\ Universitas Lancang Kuning \\ Jl. Yos Sudarso Km 08 Rumbai Pekanbaru, Riau 28266 \\ Juanim \\ Universitas Pasundan \\ Jl. Tamansari No.6-8, Kec. Bandung Wetan, Bandung, Jawa Barat 40116 \\ received: 2/1/20; revised: 7/5/20; approved: 29/6/20

\begin{abstract}
In addition to being provided by private service providers, satisfactory services are also important for a government-owned service provider to build customer trust. The purpose of this research is to identify whether satisfaction from service and participation affects customer trust in governmentowned hospitals. The research was conducted at RSUD Arifin Ahmad Pekanbaru using a survey method on a sample of outpatient service recipients. The sample consisted of 100 people who were selected using accidental sampling. The data were collected using a questionnaire and the analysis tools, namely SEM and WarpPLS software. The results showed that service and patient participation in services has a significant effect on patient satisfaction. In addition, patient satisfaction also has a significant effect on patient trust in government-owned hospitals.
\end{abstract}

Keywords: participation; patient satisfaction; patient trust; service

\section{INTRODUCTION}

Nowadays, the marketing of hospital health services is very important in carrying out the hospital's role as a service provider. Government-owned (public) hospitals as health service providers are currently very competitive with private hospitals. Patients as customers are able to obtain complete information due to technological developments. Satisfying service is one important aspect that patients consider to choose the best health services. Information services also make public hospitals continue to improve the quality of their services to their patients.

Based on the data of the Riau Provincial Health Service in 2015, there were 64 units of operating hospitals that provide 5,008 beds to serve their patients. Health services provided at public hospitals are highlighted due to more advantages they have in comparison to private hospitals, especially in the budgeting or hospital financing sector, which supported by the government budget.

An example of a public hospital supported by the government budget is The Regional General Hospital (RSUD - Rumah Sakit Umum Daerah) of Arifin Achmad. As a referral hospital owned by the government in Riau Province, this hospital has the motto "your satisfaction is our happiness" and has a vision of "becoming an independent education hospital with excellent services that meet international standards". This supports the good intentions of the government to provide the best service for the people of Riau Province. This is also in accordance with the provisions of Law No. 44 of 2009 concerning hospitals.

Health services related to customer satisfaction is an interesting issue. Since patients as customers are very dependent on optimal and quality hospital services. This quality service does not only become the expectation of the customers, but it also affects patient satisfaction and trust. The low quality of domestic health services causes patients to seek treatment abroad. This shows that the quality of service in the country must be improved to build patient satisfaction and trust.

According to Imran and Ramli (2019), patients who are satisfied with the hospital services will always make the hospital as a reference for treatment and also recommend it to others. Thus, the hospital is able to continue to provide sustainable services. Although supported by the government budget, public hospitals can provide low-quality services, this can eventually lead to hospitals being abandoned by their customers. 
Moreover, intense competition with private hospitals that offer quality services, including hospitals overseas such as in neighboring countries of Malaysia and Singapore, makes customers seek treatment abroad. Bitner, Zeithaml, and Gremler (2010) also explain that building relationships between industries and their customers are intended to maintain trust in the company in the long term.

Patient trust in RSUD Arifin Achmad is suboptimal in terms of dedication to patients and synergy between the hospital's motto and the workers' performance (Suroto, 2018). According to Gurviesz and Korchia (2011: 3), customers need to get more attention in order to gain customer trust.

Many problems can be seen in the field. According to Waljee et al. (2008: 1679), trust is related to patient satisfaction in receiving service. In addition, Imran and Ramli (2019) believe that satisfaction and trust are like relationships of collaborating parties in which there is mutual trust and need for both of them. Moreover, Setyorini (2008) states that the readiness of health service providers in responding to patient complaints can build patient trust in those health service providers.

In addition, Han and Hyun (2015) explain the close relationship between customer satisfaction and trust in health services. In line with $\mathrm{Su}, \mathrm{Hsu}$, and Swanson (2017) and Liang, Choi, and Joppe (2018), they found a relationship between satisfaction and trust in the service sector. In health services, Alrubaiee and Alkaa'ida (2011) confirm that patient trust is built by patient satisfaction in receiving services. Furthermore, Castaldo et al. (2016) and Zehra and Arshad (2019) also explain the relationship between satisfaction and trust.

Based on these findings and statements, it can be seen that patient satisfaction has an effect on patient confidence. Patients see the health service provider as a partner. The readiness of service providers in satisfying patients will be the basis of patient assessment, and build their trust in these service providers. The relationship between these two variables is very close, and it becomes an integral part in building patient trust in the services provided by healthcare providers.

Furthermore, several findings explain the factors that influence satisfaction. For instance, Nugraha et al. (2017) found that patient satisfaction is affected by image and service quality. Moreover, Gunawan and Saragih (2019) found that service quality and media service innovation are factors that influence the quality of service. According to Hasan and Putra (2018), the loyalty of a patient to a hospital service provider is influenced by the quality of service, image, value, and satisfaction.

In addition, $\mathrm{Wu}$ (2011) found that quality services can build customer satisfaction. Meesala and Paul (2018) concluded that, in order to provide sustainable services, service providers need to pay attention to their services, and satisfy their customers. In line with Lee,
Lee, and Kang (2012), customer satisfaction becomes an opportunity for service providers to achieve success. According to Shabbir and Malik (2016), the public and private sectors also need to provide services in order to satisfy their customers.

Other variables are closely related to patient satisfaction. since it involves several parties, including the patient, the health service provider or the hospital, and the medical and non-medical staff. In this case, Perwira (2006) states that customer participation is closely related to their satisfaction; the more customers are included in the service process, the more satisfied they would be, due to getting knowledge in the process. Moreover, Asnawi (2017) explains that in the dynamics of the development of information systems, service is related to the information system. This also applies to hospitals in which there is a strong link between customer participation and satisfaction in using a service. Jatmiko (2013) also states that customer satisfaction is needed to build customer loyalty. Customer satisfaction is mostly affected by customer education and customer participation. Customers who get new information in a service process will get better satisfaction compared to when they are not invited to communicate.

Other studies also discuss customer participation in their satisfaction. Schoenfelder, Klewer, and Kugler (2011) revealed that involving customers in service makes customers understand and be satisfied with the service. In addition, Castro et al. (2016) state that patients need to be empowered in the healing process because this will make them happy, and this is part of the treatment itself. Furthermore, Thórarinsdóttir and Kristjánsson (2014) explain that patient participation in services will make patients have a higher desire to recover and feel happy with the process.

Based on these statements related to patient satisfaction with respect to patient trust, it can be concluded that service quality and patient participation variables are unique compared to other variables. These variables are also distinguishing from previous studies. Therefore, there are several questions in this research that need to be asked: (1) in the service provided by RSUD Arifin Achmad Pekanbaru, is it true that service quality and patient participation affect patient satisfaction? (2) Does patient satisfaction affect patient trust in using the health services of this public hospital?

This research aims at identifying and analyzing the effect of service quality and participation on patient satisfaction and the effect of patient satisfaction on patient trust. The patients in this research are those that receive the service provided in RSUD Arifin Achmad Pekanbaru, which is a government-owned hospital.

\section{METHOD}

This research was conducted at Arifin Achmad Hospital in Pekanbaru, a government-owned hospital 
that serves as a central referral for hospitals in regencies located in Riau province. This research is descriptive research that provides an overview of the condition of research variables using a verification approach to answer the research questions.

Respondents in this research were inpatients or families of inpatients who receive the services provided at RSUD Arifin Achmad. From a population of 1,530 people, 100 people were selected as the research sample. The sampling technique used a proportional cluster random sampling. The sample was taken based on available service classes, which were the care classes provided by the hospital in providing inpatient services. The data was collected by distributing questionnaires to the respondents after they receive the service from the hospital.

The variables observed in this research consist of two exogenous variables, namely service quality and patient participation, and two endogenous variables, namely patient satisfaction and patient trust. In terms of the operationalization of each variable, the service quality variable has two indicators, namely the service process and proof of service provided by the service provider. Furthermore, the patient participation variable has two indicators, namely attention to patient's symptoms and request for opinions in making medical treatment decisions. In addition, the patient satisfaction variable has two indicators, namely satisfaction with the services of the medical staff and the non-medical staff. Lastly, the patient trust variable has six indicators, namely fairness, fulfillment, loyalty, transparency, integration, and reliability.

In this research, the data analysis method employed a quantitative descriptive analysis. Descriptive analysis is a method for determining the respondents' answer score in relation with the variable in question, while the quantitative method is used for conducting statistical analysis. For this research, the SEM (structural equation modeling) analysis tool is used with the WarpPLS application. The research equation used has two model structures as follows:

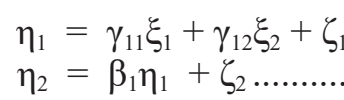

\section{RESULTS}

The findings of the research are presented based on the characteristics of the respondents, the description of the research variables, and the research model. The characteristics of respondents refer to the data of age and educational background of the respondents. The respondents' age gives an idea regarding the experience and rationality of the data. Based on the data collection, it was found that the majority of the respondents were over 51 years old. The overall age distribution of the respondents is presented in Table 1.
Table 1 shows that most of the respondents were over 51 years old $(26 \%)$. This indicates that the respondents had the experience and rationality of the actual conditions in the field, which could be assessed by responding to the questionnaire. Although there were the respondents who were under 20 years old $(9 \%)$, this data can still provide accurate information in the hospital services.

Afterward, the characteristics of the respondents were observed based on their educational background. The educational background illustrates the respondents' knowledge regarding conditions experienced when receiving services from hospitals. The data is presented in Table 2.

Table 2 shows that the majority of the respondents were senior high/vocational school graduates (42\%). This indicates that the respondents had sufficient knowledge in providing information regarding the conditions of the service they received from the hospital. On the other hand, some of the respondents were elementary school and junior high school graduates, because they came from remote areas in Riau Province.

Furthermore, the research data are presented in terms of the characteristics of the observed variables, namely service quality, patient participation, patient satisfaction, and patient trust. The description and score obtained of each variable are presented in Table 3.

Table 3 shows that the service quality variable scored 2.755, which was included in the moderate category. From the two indicators, proof of service provided was better than the service process. Then, the patient participation variable scored 2.836, which was included in the moderate category. From the two indicators, attention to patient's symptoms was better than requesting patients' opinions in taking medical treatment. Furthermore, the patient satisfaction variable scored 2.95, which was included in the moderate category. From the indicators on this variable, the patients were more satisfied with the non-medical staff compared to the medical staff. Lastly, the patient trust variable scored 3.00 , which was included in the moderate category. The results show that the indicators of loyalty to the hospital and transparency from the staff scored above average. Meanwhile, the integration indicator scored the lowest, which meant that the integration between services was still poor.

The results of the validity and reliability test of each research variable indicated that all indicators of each variable were valid. The indicators of the service quality variable had the r-count value of 0.43 and 0.61 , which were considered valid when compared to the r-table value of 0.30 . Similarly, the indicators of the patient participation variable had the r-count value of 0.45 and 0.51 respectively. Moreover, indicators of the patient satisfaction variable were considered valid with the r-count value of 0.39 and 0.56 respectively. Furthermore, the six indicators of the patient trust 
variable were considered valid with the r-count values as follows: $0.55,0.65,0.59,0.61,0.69$, and 0.67 . For the reliability test, the variables had the Cronbach alpha value as follow: service quality $=0.90$, participation $=$ 0.90 , satisfaction $=0.87$, and trust $=0.93$. Comparing to the standard value of 0.70 , all of the variables were reliable.

The results of the verification analysis using SEM analysis tools showed that the service quality and patient participation variable had a significant effect on patient satisfaction. It was also found that patient satisfaction had a significant effect on patient trust in RSUD Arifin Achmad. These findings can also be seen in Figure 1.

Based on the data above, the effect of service and patient participation on patient satisfaction was significant. In addition, it was found that service had a greater effect $(0.38: 0.22)$ compared to service participation. Moreover, it was also found that satisfaction had a significant effect on outpatient trust in RSUD Arifin Ahmad Pekanbaru.

Furthermore, the hospital is always required to provide good services and always seek to consider patients' knowledge so that they can determine the best service to be provided. The lowest value of this dimension was the question "There is an effort to involve the patient's family in the patient's healing process." This shows that the hospitals in Riau Province were inadequate and unreliable enough to provide services to patients' families.

The item on an effort to involve the patient in the healing process was moderate, since the patients were always encouraged to strive and pray for their recovery. This was a form of effort made by the staff in order to involve the patient in the healing process and the patients' families in order to help remind them of giving medicine to the patient. In addition, the item on an effort to involve the patients' families in the healing process was also in the moderate category. In other words, the effort to involve the patients' families in the healing process was good enough. The patients' family has a significant role in the patients' healing process. Especially for outpatients, the patients' family becomes their caregiver at home, so that the patients' family support can increase the chances of recovery.

In terms of services provided, hospitals were always required to provide good services and guarantee the patient's right to obtain the services provided. The lowest score of this dimension was for the statement "Patients are given the same treatment in getting services," this shows that hospitals in Riau Province were inadequate and unreliable enough to provide the same service to all patients. The item of the hospital's accuracy in providing information to patients was moderate, which indicated that the hospitals were able to provide accurate information to the patients. The accuracy of information provided to patients was considered accurate when patients got various information regarding their illness.
However, sometimes patients did not get it properly and correctly, because there were still doubts from the hospital about the patient's illness.

The item of patients are given the same treatment in getting services was included in the moderate category, and this means that the hospital was good enough in providing the same treatment to patients in providing services. However, the treatment given to patients was still different; economically disadvantaged patients were treated differently from other patients, where they were sometimes treated in a harsher and louder manner, while economically advantageous patients were treated more softly and politely. This was experienced by members of the Social Insurance Administration Organization (BPJS - Badan Penyelenggara Jaminan Sosial) who could not make an appointment or register by phone, but instead, they had to come directly and wait in long queues. Whereas economically advantageous patients were prioritized, and they could make appointment and register by phone, and even did not need to wait in queues like patients who are BPJS members.

\section{DISCUSSION}

Services at government-owned hospitals also require patient trust because, in the absence of patient trust, the patients will consider moving to private hospital services. This need is magnified by the existence of the government-run insurance service that involves private parties called BPJS. This condition makes government-owned hospitals have to improve their services. The research results revealed that satisfaction from patients in government hospitals has a significant effect on patient trust. The findings of this research are in line with Imran and Ramli (2019); Setyorini (2008); Han and Hyun (2015); Su, et. al. (2017); Liang, et. al. (2018); Alrubaiee and Alkaa'ida (2011); Castaldo, et. al. (2016); and Zehra and Arshad (2019).

Furthermore, the six indicators of the patient trust variable had an average score of 3.00, which were categorized as moderate. Specifically, the indicators with above-average scores were patient loyalty to the hospital and transparency from the staff. Meanwhile, the indicator with the lowest score was service integration, which means the integration between services in the hospital was still low. In other words, increasing patient satisfaction can increase patient trust, and in the patient satisfaction variable, both indicators have an average total score of 2.952 or categorized as moderate. On this variable, the patients were more satisfied with the non-medical staff compared to the medical staff.

This result was in line with Ondang and Shah (2018) who state that non-medical staff makes a major contribution to the patients because the patients always deal with non-medical staff before getting services from the medical staff. Therefore, good non-medical services will increase patient trust in the hospital service. 
Relating to the patient satisfaction variable, the research found that service quality and patient participation had a significant effect on patient satisfaction. The service quality variable scored 2.755 or categorized as moderate. Based on the two indicators, the roof of service scored better than the service process. In addition, the patient participation variable scored 2.836 or categorized as moderate. Based on the two indicators, attention to patients' symptoms scored better compared to the request for opinions in which patients were being consulted before being given medical treatment.

The findings in the service quality variable were in line with previous studies, such as those conducted by $\mathrm{Wu}$ (2011); Meesala and Paul (2018); Lee, et. al. (2012); Shabbir and Malik (2016); Asnawi (2017); and Jatmiko (2013) who found similar findings. In fact, proof of service at a hospital service determines patient satisfaction. Patients want a service that has clear proof and leads to healing. If the service provided is able to provide healing, then the patient will feel satisfied and have more confidence in government-owned hospitals.

Furthermore, the research result also revealed that patient participation had a significant effect on patient satisfaction. This means that patients get satisfaction from hospital services if they are mentally involved, and the attention given to them will make them happy in the healing process. This is finding conforms to the study conducted by Schoenfelder, et. al. (2011); Castro, et. al. (2016); and Thórarinsdóttir and Kristjánsson (2014) that found that patient participation in hospital services will better encourage them to recover and be happy with the process.

Based on these explanations, the results of this research have implications for health service management. So far, health services prioritize service staff and service facilities to create patient satisfaction and trust in the existing services. However, the findings in this research contribute a new finding, which is that the patients' mental state also need to get serious attention, because the source of motivation for patients to use health services is based on the patients perspective; patients want to recover and patients also have a source of funding. Therefore, a humanist approach to health care is important as a part of health service management.

\section{CONCLUSION}

The findings in this research indicated that patient satisfaction in government-owned hospitals was affected by the quality of services provided, particularly in the aspect of proof of service. In addition, patient satisfaction was also affected by patient participation in the service process. Moreover, patient satisfaction had a significant effect on patient trust in using governmentowned hospital services. This proves that public and private hospitals compete with each other to get patients.
The effort to involve the patient will make the patient satisfied and in turn, putting trust in the health service.

\section{REFERENCE}

Alrubaiee, L., \& Alkaa'ida, F. 2011. The mediating effect of patient satisfaction in the patients' perceptions of healthcare quality-patient trust relationship. International Journal of Marketing Studies, 3(1), 103.

Asnawi, M. F. 2017. Pengaruh Kualitas Sistem, Kualitas Informasi, Kualitas Layanan, Dan Partisipasi Pengguna Terhadap Kepuasan Pengguna Sistem: Studi Kasus Pada Bagian Operasional Vsat Ip Pt. Semesta Citra Media. Jurnal Lentera ICT, 2(1), 37-50.

Bitner, M. J., Zeithaml, V. A., \& Gremler, D. D. 2010. Technology's impact on the gaps model of service quality. In Handbook of service science (pp. 197218). Springer, Boston, MA.

Castaldo, S., Grosso, M., Mallarini, E., \& Rindone, M. 2016. The missing path to gain customers loyalty in pharmacy retail: The role of the store in developing satisfaction and trust. Research in Social and Administrative Pharmacy, 12(5), 699-712.

Castro, E. M., Van Regenmortel, T., Vanhaecht, K., Sermeus, W., \& Van Hecke, A. 2016. Patient empowerment, patient participation and patientcenteredness in hospital care: a concept analysis based on a literature review. Patient education and counseling, 99(12), 1923-1939.

Gunawan, Y. I., \& Saragih, M. 2019. Pengaruh Kualitas Pelayanan Medis Dan Inovasi Layanan Administrasi Terhadap Kepuasan Pasien. Jurnal Manajemen Kewirausahaan, 16(1), 33-42.

Gurviesz \& Korchia. 2011. Marketing fields forever, Kingston Business School, Liverpool

Han, H., \& Hyun, S. S. 2015. Customer retention in the medical tourism industry: Impact of quality, satisfaction, trust, and price reasonableness. Tourism Management, 46, 20-29.

Hasan, S., \& Putra, A. H. P. K. 2018. Loyalitas Pasien Rumah Sakit Pemerintah: Ditinjau Dari Perspektif Kualitas Layanan, Citra, Nilai dan Kepuasan. Jurnal Manajemen Indonesia, 18(3), 184-196.

Imran, B., \& Ramli, A. H. 2019. Kepuasan Pasien, Citra Rumah Sakit dan Kepercayaan Pasien di Provinsi Sulawesi Barat. In Prosiding Seminar Nasional Pakar (pp. 2-48).

Jatmiko, R. 2013. Pengaruh Pengelolaan Masalah Pelanggan, Edukasi Pelanggan Dan Partisipasi Pelanggan Terhadap Loyalitas Pelanggan. Jurnal Ilmu Manajemen dan Akuntansi Terapan (JIMAT), 4(2), 100-107.

Lee, S. M., Lee, D., \& Kang, C. Y. 2012. The impact of high-performance work systems in the healthcare industry: employee reactions, service quality, 
customer satisfaction, and customer loyalty. The Service Industries Journal, 32(1), 17-36.

Liang, L. J., Choi, H. C., \& Joppe, M. 2018. Exploring the relationship between satisfaction, trust and switching intention, repurchase intention in the context of Airbnb. International Journal of Hospitality Management, 69, 41-48.

Meesala, A., \& Paul, J. 2018. Service quality, consumer satisfaction and loyalty in hospitals: Thinking for the future. Journal of Retailing and Consumer Services, 40, 261-269.

Nugraha, N. M., Anwar, A., Priadana, M. S., \& Firdaus, O. M. 2017. Analisis Pengaruh Citra dan Kualitas Layanan Terhadap Kepuasan Pasien Serta Implikasinya Pada Komunikasi Pemasaran di Rumah Bersalin Fatimah Kota Bandung. Jurnal Teknologi dan Manajemen Industri, 3(1), 14-19.

Ondang, M. M., \& Syah, T. Y. R. 2018. How Hospital Brand Image Intervene The Impact Of Marketing Mix On Patient Loyalty. International Journal of Recent Advances in Multidisciplinary Research Vol. 05, Issue 07, pp.3959-3963, July, 2018

Schoenfelder, T., Klewer, J., \& Kugler, J. 2011. Determinants of patient satisfaction: a study among 39 hospitals in an in-patient setting in Germany. International journal for quality in health care, 23(5), 503-509.

Setyorini, D. 2008. Pengaruh Penanganan Keluhan Pelayanan Kesehatan terhadap Kepercayaan Pasien di Rumah Sakit Umum Daerah Panembahan

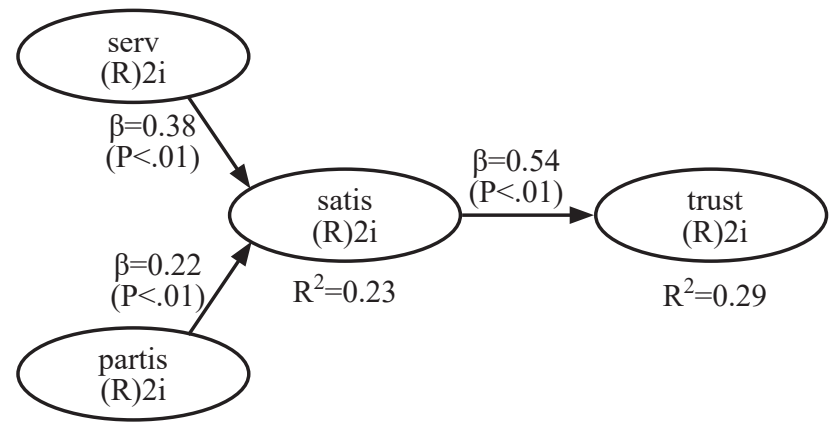

Figure 1. Full Research Model
Senopati Kabupaten Bantul. Retrieved January, 22, 2013.

Shabbir, A., \& Malik, S. A. 2016. Measuring patients' healthcare service quality perceptions, satisfaction, and loyalty in public and private sector hospitals in Pakistan. International Journal of Quality \& Reliability Management, 33(5), 538-557.

Su, L., Hsu, M. K., \& Swanson, S. 2017. The effect of tourist relationship perception on destination loyalty at a world heritage site in China: The mediating role of overall destination satisfaction and trust. Journal of Hospitality \& Tourism Research, 41(2), 180-210.

Thórarinsdóttir, K., \& Kristjánsson, K. 2014. Patients' perspectives on person-centred participation in healthcare: a framework analysis. Nursing Ethics, 21(2), 129-147.

Undang-Undang No. 44 Tahun 2009 Tentang Rumah Sakit.

Waljee, J. F., Hu, E. S., Newman, L. A., \& Alderman, A. K. 2008. Correlates of patient satisfaction and provider trust after breast-conserving surgery. Cancer: Interdisciplinary International Journal of the American Cancer Society, 112(8), 1679-1687.

Wu, C. C. 2011. The impact of hospital brand image on service quality, patient satisfaction and loyalty. African Journal of Business Management, 5(12), 4873-4882.

Zehra, S. J., \& Arshad, U. 2019. Brand Trust And Image: Effect On Customers'satisfaction. Journal of Marketing and Logistics (JML), 2, 50-64.

Table 1. Respondents' Age

\begin{tabular}{cccc}
\hline No & Age & Total & Percentage \\
\hline 1 & $<20$ & 9 & $9.0 \%$ \\
2 & $20 \mathrm{~s} / \mathrm{d} \mathrm{30}$ & 21 & $21.0 \%$ \\
3 & $31 \mathrm{~s} / \mathrm{d} \mathrm{40}$ & 25 & $25.0 \%$ \\
4 & $41 \mathrm{~s} / \mathrm{d} 50$ & 19 & $19.0 \%$ \\
5 & $>51$ & 26 & $26.0 \%$ \\
\hline Total & & 100 & $100.0 \%$ \\
\hline Source: Survey Data & &
\end{tabular}

Table 2. Respondents' Educational Background

\begin{tabular}{clcc}
\hline No & Educational Background & Total & Percentage \\
\hline 1 & Primary School & 12 & $12.0 \%$ \\
2 & Junior High School & 18 & $18.0 \%$ \\
3 & Senior High/Vocational School & 42 & $42.0 \%$ \\
4 & Bachelor & 28 & $28.0 \%$ \\
\hline Total & 100 & $100.0 \%$ \\
\hline Source: Survey Data & &
\end{tabular}


Table 3. Respondents' Responses on each Research Variable

\begin{tabular}{clccccccc}
\hline No & Service quality & 5 & 4 & 3 & 2 & 1 & Average & Category \\
\hline 1 & Service process & 5 & 21 & 24 & 38 & 12 & 2.685 & Moderate \\
2 & Proof of service & 5 & 29 & 29 & 20 & 18 & 2.825 & Moderate \\
\hline & Total Score Average & & & & & & 2.755 & Moderate \\
\hline No & Patient participation & 5 & 4 & 3 & 2 & 1 & Avg. & Category \\
\hline 1 & Attention to patient's symptoms & 3 & 34 & 28 & 20 & 16 & 2.9025 & Moderate \\
2 & Request for opinions & 3 & 30 & 29 & 19 & 21 & 2.77 & Moderate \\
\hline & Total Score Average & & & & & & 2.836 & Moderate \\
\hline No & Patient Satisfaction & 5 & 4 & 3 & 2 & 1 & Avg. & Category \\
\hline 1 & Medical staff & 7 & 30 & 26 & 20 & 19 & 2.8575 & Moderate \\
2 & Non-medical staff & 9 & 34 & 26 & 17 & 15 & 3.0475 & Moderate \\
\hline & Total Score Average & & & & & & 2.9525 & Moderate \\
\hline No & Patient trust & 5 & 4 & 3 & 2 & 1 & Avg. & Category \\
\hline 1 & Fairness & 6 & 19 & 30 & 32 & 13 & 2.745 & Moderate \\
2 & Fulfillment & 5 & 23 & 45 & 18 & 10 & 2.948 & Moderate \\
3 & Loyalty & 15 & 37 & 26 & 21 & 1 & 3.428 & Good \\
4 & Transparency & 16 & 34 & 28 & 20 & 3 & 3.418 & Good \\
5 & Integration & 3 & 20 & 30 & 33 & 14 & 2.648 & Moderate \\
6 & Reliability & 4 & 17 & 48 & 20 & 11 & 2.843 & Moderate \\
\hline & Total Score Average & & & & & 3.005 & Moderate \\
\hline Source & Survey Data & & & & & &
\end{tabular}

Source: Survey Data 